\title{
Sweat testing for cystic fibrosis
}

\section{Diagnostic screening with a combination chloride ion-selective electrode}

\author{
P. T. BRAY, G. C. F. CLARK, G. J. MOODY, G. THOMAS, AND J. D. R. THOMAS \\ From the Department of Child Health, Welsh National School of Medicine, and Department of Chemistry, \\ University of Wales Institute of Science and Technology, Cardiff
}

SUMMARY Screening of sweat chloride in newborn infants with the Orion Skin Chloride Measuring System and incorporating some procedural innovations is described. The results indicate that while diagnostic screening for cystic fibrosis can be readily undertaken, the test with the chloride ionselective electrode is best left at least to the second day of life or later because of insufficient sweating in very young babies. Measurements on 2 babies with cystic fibrosis are also discussed.

The major diagnostic criterion for cystic fibrosis (CF) is a positive sweat test (Gibson, 1975) such as that using the Gibson and Cooke (1959) technique with its many in-built safeguards against errors (Bray et al., 1975). However, because of the need for laboratory analyses the technique is time consuming. Although this is of little consequence in confirmatory diagnosis, it is not a test that can be applied to the routine screening of newborn infants.

Many screening tests have been examined, including that using the combination ion-selective electrode designed to give immediate results (Bray et al., 1975). This test is frequently associated with pilocarpine iontophoresis for sweat stimulation and has recently been assessed for possible sources of error (Bray et al., 1977a, b). As a result, certain procedural modifications have been suggested for incorporating into the Orion Model 417 Skin Chloride Measuring System. These are concerned with electrode care and maintenance, skin washing, nature of pilocarpine substrate, and other factors in the iontophoresis stage of sweat stimulation. We report the results of a screening programme incorporating the procedural changes.

\section{Method}

An assistant was trained to use the step procedure described below, based on the Orion Model 417 Skin Chloride Measuring System consisting of a Model 417 combined current source and meter, a model 97-17-00 combination chloride electrode, and ancillary equipment. The iontophoresis electrodes

Received 6 December 1977 were modified so that the metal surfaces were flush with the skin and a groove cut between them to prevent direct electrical contact. Instead of the original Orion felt pads which tended to dry out during storage, cellulose phosphate filter paper was used because of ease of handling. Ordinary filter paper is not recommended because of the slightly painful sensation experienced during experiments with adult volunteers. The paper was cut into $1.5 \times 2 \mathrm{~cm}$ and $1 \times 2 \mathrm{~cm}$ pieces for the anode and cathode pads respectively. The anode pads were soaked with $0 \cdot 1 \mathrm{~cm}^{3}$ of $0 \cdot 1 \mathrm{~mol} / 1$ pilocarpine nitrate solution and dried. The cathode pads were similarly treated with $10 \% \mathrm{~m} / \mathrm{v}$ potassium sulphate.

The internal reference electrode filling solution used was $1 \mathrm{~mol} / \mathrm{l}$ in potassium nitrate, $0.02 \mathrm{~mol} / 1$ in sodium chloride and saturated with silver chloride.

\section{Step procedure}

(A) Initial setup. (1) Fill the reference electrode. Check the battery in the meter. (2) Calibrate the electrode with $0.2 \mathrm{~mol} / 1$ and $0.1 \mathrm{~mol} / 1$ sodium chloride solution.

(B) Test procedure. (1) Wash the volar surface of the right forearm with isopropanol (Mediswab-Pharmax) followed by two washings with gauze soaked in deionised water. Dry the site with a tissue. (2) Place two anode papers and two cathode papers on the iontophoresis block. Add 120 and $100 \mathrm{~mm}^{3}$ respectively of deionised water with a Finnpipette. Leave for $30 \mathrm{~s}$ for the water to be absorbed. (3) Place the block on the arm and attach with a Velcro strap. Turn on the current and leave at $1.5 \mathrm{~mA}$ for 5 
minutes. (4) Remove the iontophoresis block, wash the skin with a gauze soaked in deionised water, and dry with a tissue. (5) Cover the site with a $2 \cdot 5 \mathrm{~cm}$ square of plastic film (Nescofilm) and leave for 3 minutes, or longer if sweating is slow. (6) Remove the film and quickly place the dry electrode on the sweat. Record the meter reading as soon as it settles.

(C) Final stage. Drain the electrode and wash out the body with deionised water. Store dry.

The screening was carried out on newborn infants at the University of Wales Hospital and was aimed not to interfere with ward routine and not to distract ward staff from their normal duties.

\section{Results}

1218 routine screening tests were attempted, but 5 were incomplete because the babies were taken away for paediatric checks. Sweating could not be induced in a further 8 cases so that the analysis is based on 1205 tests.

The results of screening gave a mean sweat chloride of $34.4(/ \mathrm{mmol} / \mathrm{l})(\mathrm{SD} 12 \cdot 7(/ \mathrm{mmol} / \mathrm{l})$, the standard error (SE) of this mean being $0.36 \mathrm{mmol} / \mathrm{l}$. There was little difference in the sweat chloride for the 594 males (mean $33.4 \mathrm{mmol} / 1 \pm 0.51 \mathrm{SE}$ ) and the 621 females (mean $34.9 \mathrm{mmol} / 1 \pm 0.52$ ), the t-distribution value of 2.06 being near to that of 1.96 for a probability of $0 \cdot 05$. A similar result applies also to bottle feeding ( 492 cases: mean $32.0 \mathrm{mmol} / 1 \pm$ $0 \cdot 50)$ compared with breast feeding (482 cases: mean $34 \cdot 4 \mathrm{mmol} / 1 \pm 0 \cdot 50$ ).

Classified analyses according to age and sweat chloride levels respectively are shown in Table 1 , while Table 2 summarises the relation between a subjective estimate of sweating, sweat chloride, and age. The quantity of sweat was assessed subjectively on a 4-point scale ranging from 'no sweat' to 'excessive'. In this context it is notable that it was generally more difficult to obtain sufficient sweating in babies of about 1 day old. Preterm babies are overrepresented in the low degree of sweating ranges.

Attempts were made in some cases to collect sweat from the same pilocarpine iontophoresis area as was used for measuring with the chloride ion-selective electrode, the collection being made after ionselective electrode measurement and after washing the skin area twice with gauze pads soaked in deionised water and drying with a fresh paper tissue. This was intended for chloride analyses by chloridometer, but the sweat sample size of about $15 \mathrm{mg}$ was far below the minimum of $100 \mathrm{mg}$ recommended for use in the chloridometer (Gibson and Cooke, 1959). The planned correlation study was therefore carried

Table 1 Sweat chloride levels based on age and chloride distribution

\begin{tabular}{|c|c|c|c|c|c|}
\hline \multicolumn{3}{|l|}{ Age distribution } & \multicolumn{3}{|c|}{ Chloride level distribution } \\
\hline Age group/day & No. in group & $\begin{array}{l}\text { Mean chloride } \\
\quad(/ \mathrm{mmol})( \pm S E)\end{array}$ & $\begin{array}{l}\text { Chloride group } \\
\text { (mmol/l) }\end{array}$ & No. in group & $\begin{array}{l}\text { Mean age/day } \\
( \pm S E)\end{array}$ \\
\hline $\begin{array}{r}0-0 \cdot 5 \\
0 \cdot 5-1 \cdot 0 \\
1 \cdot 0-1 \cdot 5 \\
1 \cdot 5-2 \cdot 0 \\
2 \cdot 0-2 \cdot 5 \\
2 \cdot 5-3 \cdot 0 \\
3 \cdot 0-3 \cdot 5 \\
3 \cdot 5-4 \cdot 0 \\
4 \cdot 0-4 \cdot 5 \\
4 \cdot 5-5 \cdot 0 \\
5 \cdot 0-20\end{array}$ & $\begin{array}{r}62 \\
157 \\
160 \\
174 \\
179 \\
118 \\
76 \\
56 \\
46 \\
46 \\
131\end{array}$ & $\begin{array}{l}38(1 \cdot 3) \\
39(1 \cdot 1) \\
39(0 \cdot 85) \\
37(0 \cdot 88) \\
34(0 \cdot 90) \\
33(1 \cdot 1) \\
32(1 \cdot 5) \\
30(1 \cdot 4) \\
29(1 \cdot 8) \\
27(1 \cdot 8) \\
27(1 \cdot 0)\end{array}$ & $\begin{array}{l}0-5 \\
5-10 \\
10-15 \\
15-20 \\
20-25 \\
25-30 \\
30-35 \\
35-40 \\
40-45 \\
45-50 \\
50-55 \\
55-60 \\
60-100^{*}\end{array}$ & $\begin{array}{r}2 \\
24 \\
62 \\
115 \\
134 \\
136 \\
138 \\
136 \\
160 \\
241 \\
34 \\
13 \\
10^{*}\end{array}$ & $\begin{array}{l}0.9(0.06) \\
3.7(0.50) \\
4.3(0.42) \\
3.5(0.4) \\
3.1(0.17) \\
2.7(0.14) \\
2.7(0.15) \\
2.7(0.19) \\
2.0(0.13) \\
1.8(0.08) \\
1.7(0.19) \\
1.9(0.26) \\
-\end{array}$ \\
\hline
\end{tabular}

*The individual values with ages in parentheses are: 65† (1.04), 70† (5.48), 70† (3.25), $70(20), 70(1 \cdot 25), 70 \dagger(0 \cdot 85), 90(3 \cdot 17), 90(0 \cdot 58), 100$ (3.04), 100+ (0.96).

tTrace sweating only.

Table 2 Mean sweat chloride levels according to degree of sweating

\begin{tabular}{|c|c|c|c|c|c|}
\hline \multirow[t]{2}{*}{ Sweating class* } & \multirow[t]{2}{*}{$n$} & \multicolumn{2}{|c|}{ Chloride (mmol/l) } & \multicolumn{2}{|l|}{ Age/day } \\
\hline & & Mean $( \pm S E)$ & Range & Mean $( \pm S E)$ & Range \\
\hline $\begin{array}{l}1 \\
2 \\
3 \\
4\end{array}$ & $\begin{array}{r}3 \\
850 \\
320 \\
32\end{array}$ & $\begin{array}{l}45(14) \\
36(0.41) \\
30(0.68) \\
30(2.3)\end{array}$ & $\begin{array}{r}10-65 \\
3-100 \\
7-70 \\
8-70\end{array}$ & $\begin{array}{l}1.6(0.33) \\
2.3(0.07) \\
3.3(0.13) \\
3.3(0.31)\end{array}$ & $\begin{array}{l}1 \cdot 0-2 \cdot 3 \\
0 \cdot 1-20 \\
0 \cdot 1-20 \\
0 \cdot 8-7 \cdot 6\end{array}$ \\
\hline
\end{tabular}

*Sweating classes: $1=$ no sweating; $2=$ trace; $3=$ moderate; $4=$ excessive. 
out in the laboratory with sufficient sweat samples from the 23 adult volunteers, when a correlation coefficient of 0.96 was obtained between chloride measurements by ion-selective electrode and the Radiometer Model CMT 10 Chloridometer.

Screening could not interfere with the ward activities of bathing and feeding, thus effectively reducing morning screening sessions to less than 3 hours-between about 09.45 (frequently later) and 12.45 hours - this time being further eroded by the babies being required for paediatric checks. The best screening facility was a separate room adjacent to the nursery, but nevertheless extra time was frequently taken up by the operator in reassuring mothers. A less convenient location is a screening room some distance away from the nursery and its records.

Care and maintenance of the Orion Skin Chloride Measuring System demanded that the batteries of the meter be changed once (after 460 tests) and that the chloride combination electrode be replaced after 939 tests. After cleaning and repolishing of the membrane surface, the discarded electrode was satisfactory for further service.

\section{Discussion}

Several papers describe sweat chloride data obtained by chloride ion-selective electrode monitoring on the skin surface after sweat stimulation by pilocarpine iontophoresis. Those reporting sweat chloride results and not including previously known CF cases are summarised in Table 3.

Important points in the present screening include those instances of high sweat chloride, the difficulty of obtaining sufficient sweating, and the extent to which the Orion Skin Chloride Measuring System can be used in conjunction with meconium analysis for reducing the incidence of false-positive results and thus recognising cases of CF.

Fifty-seven cases (Table 1) gave a sweat chloride $>50 \mathrm{mmol} / \mathrm{l}$, but in no instance did the BoehringerMannheim meconium test strip (BM test), electroimmunoassay of albumin, or the determination of albumin : $\alpha_{1}$-antitrypsin ratio carried out independently of the ion-selective electrode screening give a positive indication of CF. Conversely, 3 of the 4 cases included in this screening and independently found to have meconium albumin $>5 \mathrm{mg} / \mathrm{g}$ dry weight gave 23,26 , and $48 \mathrm{mmol} / 1$ sweat chloride respectively; the fourth case ( $<1$ day old) did not produce sweat.

It was observed that sweat chloride fell with age (Table 1) and that sweat induction was generally difficult in very young babies (Table 2). Furthermore, the 8 cases on which the test could not be carried out because of no sweating were all under 1.3 days old $(6<0.8$ day). This indicates that screening should not be performed until the second day or later.

No cases of CF were found among those screened. However it was possible to examine 2 such cases born in other hospitals which are not included in the above analysis. In Case 1 ( 25 days old) the ionselective electrode procedure gave $90 \mathrm{mmol} / 1$ chloride compared with $90 \mathrm{mmol} / \mathrm{l}$ obtained by the Gibson and Cooke (1959) procedure. The meconium data, the BM test strip, albumin $(469 . \mathrm{mg} / \mathrm{g}$ dry weight), and albumin : $\alpha_{1}$-antitrypsin ratio $(7 \cdot 2)$ were all positive, as well as the Gibson and Cooke sodium $(106 \mathrm{mmol} / \mathrm{l})$. Case 2 (21 days) presented with meconium ileus, was severely jaundiced and dehydrated. Sweat induction was difficult and was carried out in the interscapular area with an ion-selective electrode/sweat chloride of $70 \mathrm{mmol} / \mathrm{l}$. A confirmatory Gibson and Cooke (1959) sweat analysis was not carried out since insufficient sweat was obtained, but necropsy examination indicated $\mathrm{CF}$.

\section{Conclusion}

Mass CF screening of newborns with chloride ionselective electrodes is feasible within the limitations of ward routines by personnel prepared to follow simplified instructions for using and maintaining the Orion Sweat Chloride Measuring System. However, the difficulty of insufficient sweating in very young

Table 3 Sweat chloride studies based on ion-selective electrode data after pilocarpine iontophoresis

\begin{tabular}{|c|c|c|c|c|}
\hline \multirow[t]{2}{*}{ No. of subjects } & \multicolumn{2}{|c|}{ Chloride (mmol/l) } & \multirow[t]{2}{*}{ Ion-selective electrode system used } & \multirow[t]{2}{*}{ Reference } \\
\hline & Range & Mean $( \pm S D)$ & & \\
\hline $\begin{array}{c}4000 \\
2061 \\
47 \\
409 \\
400 \dagger \\
1205\end{array}$ & $\begin{array}{l}- \\
\overline{10}-50 \\
7-57 \\
10-90 \\
3-100\end{array}$ & 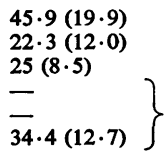 & $\begin{array}{l}\text { Beckman model } 39187 \text { silver billet* } \\
\text { Orion } 94-17 \text { chloride electrode* } \\
\text { Orion } 96-17 \\
\text { Orion } 97-17 \text { in Model } 417 \text { Measuring } \\
\text { System }\end{array}$ & $\begin{array}{l}\text { Gürson et al. (1973) } \\
\text { Kopito and Shwachman (1969) } \\
\text { Cherian and Hill (1971) } \\
\text { Armstrong and Kramer (1971) } \\
\text { This study }\end{array}$ \\
\hline
\end{tabular}

*These electrodes are not of the combination type.

†This includes 1 CF case diagnosed in the screening programme. 
babies indicates that screening should be delayed until the second day or later. With the present fashion for short hospital stays after confinement, screening must be carried out quickly. Finally the sweat chloride screening test used in conjunction with meconium analysis may reduce the incidence of false-positive results, but a much larger screening programme is required to confirm this.

We thank the Cystic Fibrosis Research Trust and the Medical Research Council for financial support; the North Atlantic Treaty Organisation for travel grants; Dr H. C. Ryley, Department of Medical Microbiology, Welsh National School of Medicine, for the meconium data; and Mrs M. Fear, Senior Nursing Officer, Maternity Unit, University Hospital of Wales and her staff for co-operation.

\section{References}

Armstrong, D., and Kramer, J. C. (1971). A sweat chloride test useful in neonatal screening in a general hospital. (Abst.) Orion Research Incorporated Newsletter, 3, 28.

Bray, P. T., Clark, G. C. F., Moody, G. J., and Thomas, J. D. R. (1975). A Perspective of Sodium and Chloride Ion-sensitive Electrode Sweat Tests for Screening in Cystic
Fibrosis. University of Wales Institute of Science and Technology, Cardiff.

Bray, P. T., Clark, G. C. F., Moody, G. J., and Thomas, J. D. R. (1977a). Sweat testing for cystic fibrosis: characteristics of a combination chloride ion-selective electrode. Clinica Chimica Acta, 77, 69-76.

Bray, P. T., Clark, G. C. F., Moody, G. J., and Thomas, J. D. R. (1977b). Sweat testing for cystic fibrosis: errors associated with the in-situ sweat test using chloride ionselective electrodes. Clinica Chimica Acta, 80, 333-338.

Cherian, A. G., and Hill, J. G. (1971). Experience with use of chloride sensitive skin electrode in detection of cystic fibrosis. (Abst.) Clinical Chemistry, 17, 652.

Gibson, L. E. (Chairman) (1975).GAP Conference on sweat testing, February 6-7, 1975, Hilton Head, S.C.

Gibson, L. E., and Cooke, R. E. (1959). A test for concentration of electrolytes in sweat in cystic fibrosis of the pancreas utilizing pilocarpine iontophoresis. Pediatrics, 23, 545-549.

Gürson, C. T., Sertel, H., Gürkan, M., and Pala, S. (1973). Newborn screening for cystic fibrosis with the chloride electrode and neutron activation. Helvetica Paediatrica Acta, 28, 165-174.

Kopito, L., and Shwachman, H. (1969). Studies in cystic fibrosis: determination of sweat electrolytes in situ with direct reading electrodes. Pediatrics, 43, 794-798.

Correspondence to Dr J. D. R. Thomas, Chemistry Department, University of Wales Institute of Science and Technology, Cardiff CF1 3NU. 